Brit. J. industr. Med., 1955, 12, 81.

\title{
MORTALITY FROM LUNG CANCER IN ASBESTOS WORKERS
}

\author{
BY \\ RICHARD DOLL \\ From the Statistical Research Unit, Medical Research Council, London
}

(RECEIVED FOR PUBLICATION AUGUST 10, 1954.)

Sixty-one cases of lung cancer have been recorded in persons with asbestosis (Boemke, 1953 ; Hueper, 1952) since Lynch and Smith (1935) reported the first case. In view of the infrequency of asbestosis, this large number of cases suggests-but does not prove-that lung cancer is an occupational hazard of asbestos workers. The strongest evidence that it may be a hazard has been produced by Merewether and by Gloyne. Merewether (1949) found that lung cancer was reported at necropsy in $13.2 \%$ of cases of asbestosis (31 out of 235) but in only $1.3 \%$ of cases of silicosis (91 out of 6,884) and Gloyne (1951), on personal examination, found lung cancer in $14.1 \%$ of necropsies on subjects with asbestosis $(17$ out of 121 ) against $6.9 \%$ in silicotics (55 out of 796). Neither author gave full details of the sex composition of the groups examined, but since women form a higher proportion of asbestos workers than of persons employed in occupations liable to give rise to silicosis (coal-miners, stonemasons, pottery workers, foundrymen, metal grinders) and since lung cancer is less common among women, the differences in the proportions of cancer cases cannot be accounted for by differences in sex distribution. In fact the proportions which are more properly comparable with the findings in silicotic subjects are the proportions of lung cancer found among men with asbestosis, $17 \cdot 2 \%$ in Merewether's series and $19.6 \%$ in Gloyne's.

Animal experiments are inconclusive. A positive result was reported by Nordmann and Sorge (1941) who found that of 10 mice which had been exposed to asbestos dust and survived for 240 days, two developed lung carcinoma. Smith (1952), however, considers that one of the "carcinomas" was, in fact, an example of squamous metaplasia and that the other, an adenocarcinoma, may have developed spontaneously from the common mouse adenoma. A negative result has been reported by Vorwald and Karr (1938). The majority of workers (cited by
Hueper, 1952) consider that a causal relationship between asbestosis and lung cancer is either proved or is highly probable and the reality of the relationship was agreed at the recent International Symposium on the Endemiology of Lung Cancer (Council of the International Organizations of Medical Sciences, 1953). A minority, however, remains sceptical (Cartier, 1952; Warren, 1948), and, according to Hueper (1952), Lanza and Vorwald, so that it was thought desirable to undertake a fresh investigation.

\section{Necropsy Data}

Since 1935, records have been collected of all the coroners' necropsies on persons known to have been employed at a large asbestos works.* Pathological diagnoses in 105 consecutive cases are summarized in Table 1. Details of the cases in

TABLE 1

CAUSES OF DEATH DIAGNOSED AT NECROPSY AMONG PERSONS EMPLOYED AT AN ASBESTOS WORKS (1933-52)

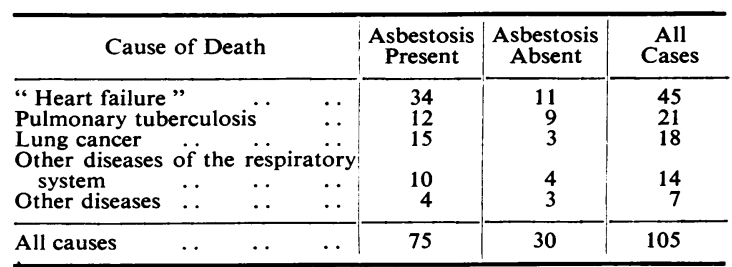

which lung cancer was found are shown in Table 2. During the first half of the period eight deaths occurred in which lung cancer was found in association with asbestosis, while in the second half of the period there were seven such cases and a further three in which lung cancer was found without asbestosis. The number of asbestos workers employed at the works increased steadily from 1914,

* Necropsies on asbestos workers are ordered by the coroner when in his opinion, there may be a question of asbestosis being a contributory cause of death. 
TABLE 2

OCCUPATIONAL HISTORY AND NECROPSY DATA OF ASBESTOS WORKERS WITH PRIMARY LUNG CANCER

\begin{tabular}{|c|c|c|c|c|c|c|c|c|c|}
\hline \multirow{2}{*}{$\begin{array}{c}\text { Year } \\
\text { of } \\
\text { Death }\end{array}$} & \multirow{2}{*}{$\begin{array}{l}\text { Sex } \\
\text { and } \\
\text { Age }\end{array}$} & \multirow[b]{2}{*}{ Occupation } & \multirow{2}{*}{$\begin{array}{c}\text { Period } \\
\text { of } \\
\text { Exposure }\end{array}$} & \multirow{2}{*}{$\begin{array}{c}\text { Years } \\
\text { of } \\
\text { Exposure }\end{array}$} & \multirow{2}{*}{$\begin{array}{c}\text { Years of } \\
\text { Exposure } \\
\text { before } \\
\text { Jan. 1, } \\
1933\end{array}$} & \multirow{2}{*}{$\begin{array}{l}\text { Years } \\
\text { from } \\
\text { First } \\
\text { Exposure } \\
\text { to Death }\end{array}$} & \multirow{2}{*}{$\begin{array}{l}\text { Years } \\
\text { from Last } \\
\text { Exposure } \\
\text { to Death }\end{array}$} & \multicolumn{2}{|c|}{ Pathological Report } \\
\hline & & & & & & & & Asbestosis & $\begin{array}{l}\text { Histological Type of } \\
\text { Primary Lung Cancer }\end{array}$ \\
\hline 1935 & M. 62 & Weaver & 1919-32 & 13 & 13 & 16 & 3 & Present & "Carcinoma" \\
\hline 1935 & M. 54 & Weaver & 1909-32 & 23 & 23 & 26 & 3 & , & Epithelial carcinoma \\
\hline 1936 & M. 65 & Fiberizer & $1913-36$ & 23 & 19 & 23 & Less than 1 & , & Endothelioma of pleura \\
\hline 1938 & M. 47 & Weaver & $\left\{\begin{array}{l}1910-12 \\
1920-37\end{array}\right.$ & 19 & 14 & 28 & 1 & , & "Carcinoma", \\
\hline 1939 & M. 49 & Disintegrater & $\left\{\begin{array}{l}1910-14 \\
1919-39\end{array}\right.$ & 24 & 17 & 29 & Less than 1 & " & "Carcinoma" \\
\hline 1940 & M. 52 & Disintegrater & $\left\{\begin{array}{l}1911-12 \\
1919-21 \\
1923-39\end{array}\right.$ & 22 & 15 & 29 & Less than 1 & ", & "Carcinoma" \\
\hline 1941 & M. 52 & Weaver & $\left\{\begin{array}{l}1913-19 \\
1924-38\end{array}\right.$ & 20 & 14 & 28 & 3 & " & Oat-celled carcinoma \\
\hline 1942 & M. 59 & Bag carrier & $1913-41$ & 28 & 19 & 29 & 1 & " & Oat-celled carcinoma \\
\hline 1948 & M. 59 & Weaver & $\left\{\begin{array}{l}1912-14 \\
1918-48\end{array}\right.$ & 32 & 16 & 36 & Less than 1 & " & Anaplastic carcinoma \\
\hline 1948 & M. 53 & Weaver & $1922-35$ & 13 & 10 & 26 & 13 & ", & "Carcinoma" \\
\hline 1948 & M. 48 & Spinner & $1922-48$ & 26 & 10 & 26 & Less than 1 & , & "Carcinoma" \\
\hline 1948 & M. 65 & Maintenance man & $1919-48$ & 29 & 13 & 29 & Less than 1 & ,"* & Oat-celled carcinoma \\
\hline 1950 & F. 51 & Spinner & $1915-42$ & 27 & 17 & 35 & 8 & " & " Carcinoma" \\
\hline 1951 & M. 74 & Fiberizer & $1917-43$ & 26 & 15 & 34 & 8 & " & Adenocarcinoma \\
\hline 1951 & M. 60 & Weaver & $\left\{\begin{array}{l}1919-25 \\
1929-50\end{array}\right.$ & 27 & 9 & 32 & 1 & " & "Carcinoma " \\
\hline 1944 & M. 36 & Weaver & $1942-44$ & 2 & 0 & 2 & Less than 1 & Absent & Oat-celled carcinoma \\
\hline 1951 & M. 43 & Fiberizer & $1939-48$ & 9 & 0 & 12 & 3 & " & Anaplastic carcinoma \\
\hline 1952 & M. 51 & Weaver & $\left\{\begin{array}{l}1941(3 / 12) \\
1945-52\end{array}\right.$ & 7 & 0 & 11 & Less than 1 & " & "Carcinoma" \\
\hline
\end{tabular}

*Also pulmonary tuberculosis.

and a great increase in the number of lung cancer deaths was also recorded among the whole population of England and Wales over the same period. It might, therefore, have been anticipated that a larger number of cases in which the two conditions were associated would have been found in the last 10 years. National regulations for the control of asbestos dust were, however, introduced in 1931 (Asbestos Industry Regulations, 1931) and the precautions taken to prevent dust dissemination in the works had become effective by the end of the following year. All the subjects in whom the two diseases were found together had been employed for at least nine years under the old conditions, and although 11 of the 15 men and women died within 30 years of their first exposure, the association of the two conditions has not yet been found in any person taken into employment during the last 31 years (1923-53). It is, therefore, possible that the reason more cases were not found in the second half of the period is that reduced exposure to dust has already begun to lessen the incidence and severity of asbestosis.

\section{Method of Estimation of Risk}

Although the necropsy data shown in Tables 1 and 2 suggest (1) that some groups of asbestos workers have suffered an increased risk of lung cancer, and (2) that the risk may now have decreased, it is not possible to be certain of either of these propositions without a more detailed knowledge of the whole mortality experience of the workers. The first proposition has, therefore, been tested by comparing the mortality experienced by that section of the male employees of the works referred to above, who had worked for at least 20 years in "scheduled areas "*, with the mortality recorded for all men in England and Wales; and the second proposition by comparing the incidence of lung cancer among men employed for different periods under the pre-1933 conditions. The investigation was limited to the small group of men who had been employed for at least 20 years, since the labour involved in searching out the individual records of

* By "scheduled areas" is meant those areas where processes were carried on which were scheduled under the Asbestos Industry Regulations of 1931 as being dusty. 
men employed for shorter periods would be disproportionately great and, so far as was known from Table 2, would be comparatively unrewarding.

The date of birth, date of completing 20 years' work in the "scheduled areas", and, where applicable, date of ceasing employment and date and cause of death were obtained, for each man, from the records of the firm's Personnel Officer. Full details were, in most instances, already available for the men who had cèased employment as well as for the greater number who continued to be employed, since some of those who had left were registered as having asbestosis and the attention of the firm had been drawn to the death of others, in view of the possibility of the cause of death being industrial in origin. All the remaining men were successfully traced and the relevant details obtained. This was not difficult since, by limiting the study to men who had been employed in one place for 20 years, few were found to have changed their job or to have moved out of the region.

From the data the numbers of men alive in each five-year age group were counted separately for each of the years from 1922 (the first in which a man was recorded as having had 20 years' service) to 1953. A man who had completed the 20 years before the beginning of a year and who was alive at the end of it was counted, for that year, as one unit; a man who completed the period before the beginning of a year but who died during it, and a man who completed the period during a year and who survived to the end of it, were each counted, for that year, as half a unit; the one man who died the same year as he completed his 20 -year period was counted as a quarter of a unit.

The causes of death were recorded as they were given on the death certificate or, when available, as they were finally determined by necropsy. The causes were classified in five categories (see Table 4), and the numbers in each category were then compared with those which might have been expected to occur by multiplying the numbers of men alive in each fiveyear age group by the corresponding mortality rates for men in England and Wales over the same period. Because of the small numbers, however, the populations were not considered separately for each year, but were added together to form five groups living in the periods 1922-33, 1934-38, 1939-43, 1944-48, and 1949-53, and the mortality rates used for each group were those for the years 1931, 1936, 1941, 1946, and 1951. The rates for 1931 were used for the period 1922-33, rather than those for the mid-years, since disproportionately few men were under observation during the early part of the period. As an example of the method, the mortality rate for all neoplasms other than lung cancer among men in
England and Wales aged 55 to 59 in 1951 was 2.778 per 1,000. The numbers of years lived in this age group in the five years 1949-53 were respectively 15 years, 15 years, $17 \frac{1}{2}$ years, 19 years, and 19 years. The number of deaths expected in the period was, therefore, estimated to be $\left(15+15+17 \frac{1}{2}+19+\right.$ 19) $\times 2 \cdot 778 / 1,000=0 \cdot 238$. The total number of deaths expected from each category of diseases was obtained by adding the numbers thus calculated for each age group for each of the five periods.

The great majority of the men lived and, when they died, died in the town in which the works was situated, so that it would have been preferable to have based the calculation of the expected deaths on the death rates observed in that town rather than on the rates for all England and Wales. These, however, were not known in sufficient detail. Little error in the expected number of deaths from lung cancer is likely to have been introduced on this account since, according to Stocks (1952), the age-adjusted death rate for lung cancer among men in the town concerned was $96 \%$ of the rate for England and Wales. Stocks's figure was calculated only for the period $1946-49$, but the proportion is unlikely to have varied greatly over the longer period of the investigation. The expected number of deaths from all causes is, however, likely to be somewhat underestimated since the age-adjusted death rate from all causes for the town is about $25 \%$ higher than the England and Wales rate (i.e. the excess was $22 \%$ in $1950,28 \%$ in 1951 , and $22 \%$ in 1952 ).

\section{Results}

The number of men studied was 113 ; the numbers of man-years lived in each of the five periods in each age group are shown in Table 3. The total number

TABLE 3

NUMBER OF MAN-YEARS LIVED BY MEN WITH 20 OR MORE YEARS OF WORK IN A "SCHEDULED AREA"

\begin{tabular}{c|c|c|c|c|c|c}
\hline $\begin{array}{c}\text { Age } \\
\text { (years) }\end{array}$ & \multicolumn{5}{|c|}{ Period } & All \\
\cline { 2 - 6 } & $1922-33$ & $1934-38$ & $1939-43$ & $1944-48$ & $1949-53$ & Periods \\
\hline $30-$ & $0 \cdot 5$ & $0 \cdot 5$ & $1 \cdot 5$ & 0 & 0 & 2 \\
$35-$ & $4 \cdot 5$ & 2 & 11 & $17 \cdot 5$ & 9 & 44 \\
$40-$ & $9 \cdot 5$ & 16 & $33 \cdot 5$ & 48 & 55 & 162 \\
$45-$ & $9 \cdot 5$ & $19 \cdot 5$ & 50 & $78 \cdot 5$ & 84 & $241 \cdot 5$ \\
$50-$ & $6 \cdot 5$ & $25 \cdot 5$ & $39 \cdot 5$ & 85 & 96.5 & 253 \\
$55-$ & 12 & 6 & 30 & 52 & $85 \cdot 5$ & $185 \cdot 5$ \\
$60-$ & 15 & 3 & $5 \cdot 25$ & $25 \cdot 5$ & 36 & $84 \cdot 75$ \\
$65-$ & 1 & $13 \cdot 5$ & 3 & 10 & $21 \cdot 5$ & 49 \\
$70-$ & 0 & 2 & 9 & 3 & $3 \cdot 5$ & $17 \cdot 5$ \\
$75-79$ & 0 & 0 & 1 & $1 \cdot 5$ & $0 \cdot 5$ & 3 \\
\hline All ages & 58 & 88 & $183 \cdot 75$ & 321 & $391 \cdot 5$ & $1042 \cdot 25$ \\
\hline
\end{tabular}

of deaths from all causes and the number of deaths observed in each of the five disease categories, together with the expected number of deaths, are shown in Table 4. From Table 4 it appears that the men who had been exposed to asbestos dust suffered 
TABLE 4

CAUSES OF DEATH AMONG MALE ASBESTOS WORKERS COMPARED WITH MORTALITY EXPERIENCE OF ALL MEN IN ENGLAND AND WALES

\begin{tabular}{|c|c|c|c|}
\hline \multirow[b]{2}{*}{ Cause of Death } & \multicolumn{2}{|c|}{ No. of Deaths } & \multirow{2}{*}{$\begin{array}{c}\text { Test of } \\
\text { Significance } \\
\text { of Difference } \\
\text { between } \\
\text { Observed } \\
\text { and } \\
\text { Expected } \\
\text { (Value of P) }\end{array}$} \\
\hline & $\begin{array}{c}\text { No. } \\
\text { Observed }\end{array}$ & $\begin{array}{l}\text { Expected } \\
\text { on } \\
\text { England } \\
\text { and } \\
\text { Wales } \\
\text { Rates }\end{array}$ & \\
\hline $\begin{array}{l}\text { Lung cancer*: } \\
\text { with mention of asbestosis.. } \\
\text { without mention of asbestosis }\end{array}$ & $\begin{array}{r}11 \\
0\end{array}$ & $\overline{0.8}$ & \}$<0.000001$ \\
\hline $\begin{array}{l}\text { Other respiratory diseases (includ- } \\
\text { ing pulmonary tuberculosis) and } \\
\text { cardiovascular diseases: } \\
\text { with mention of asbestosis } \\
\text { without mention of asbestosis }\end{array}$ & $\begin{array}{r}14 \\
6\end{array}$ & $\overline{7 \cdot 6}$ & \}$<0.001$ \\
\hline $\begin{array}{l}\text { Neoplasms other than lung cancer } \\
\text { All other diseases } \dagger . . \quad \ldots\end{array}$ & $\begin{array}{l}4 \\
4\end{array}$ & $\begin{array}{l}2 \cdot 3 \\
4 \cdot 7\end{array}$ & \}$>0 \cdot 1$ \\
\hline$\overline{\text { All causes .. }}$ & 39 & $15 \cdot 4$ & $<0.000001$ \\
\hline
\end{tabular}

* Including one case with pulmonary tuberculosis.

†Including two cases (benign stricture of oesophagus and septicaemia) in which asbestosis was present but was not thought to have been a contributory cause of death.

an increased mortality from lung cancer, other respiratory diseases and cardiovascular diseases, in association with asbestosis, but that their mortality from other diseases was close to that expected.

Four explanations of the findings are possible : (1) that all the men who had died of lung cancer were recorded because of interest in the condition, but that some of the records of other men dying of other diseases or still alive were omitted, with consequent underestimation of the expected number of deaths ; (2) that lung cancer was incorrectly and excessively diagnosed among the asbestos workers; (3) that lung cancer was insufficiently diagnosed among the general population of England and Wales ; or (4) that the asbestos workers studied suffered an excess mortality from lung cancer.

It certainly cannot be claimed that the records of the Personnel Office were necessarily complete, but they were believed to be complete and no deficiency on this score would account for the total excess of deaths unless it were so gross that more than half the defined population had been omitted. Moreover, the number of deaths due to conditions unrelated to asbestosis was close to the estimated number and this is unlikely to have happened unless the population had been estimated approximately correctly and the deaths from all causes fully reported.

All the 11 deaths attributed to lung cancer were confirmed by necropsy and histological examination so that the excess number cannot be attributed to incorrect diagnosis among the group of asbestos workers. Some of the excess may well be due to an underestimation of the expected deaths since part of the increase in mortality attributed to lung cancer over the past 30 years is certainly due to improvements in diagnosis and in therapy (Doll, 1953). Even, however, if it were postulated that the whole of the recorded increase between 1931 and 1951 was spurious and that the real mortality from the disease throughout was that ascribed to it in 1951, the expected number of deaths is increased to only $1 \cdot 1$ and the observed excess is still grossly significant. For the actual number of lung cancer cases to be so little in excess of the expected as to be reasonably attributable to chance, it would be necessary for the expected cases to be $6 \cdot 2$, that is 5.6 times the number estimated on 1951 rates. In other words, it would be necessary to postulate that in 1951 (and throughout the previous 20 years) there was 5.6 times as much cancer of the lung as was recognized in 1931, which would mean that the condition would have to have been present and capable of detection in over $20 \%$ of all men at death. Moreover, even if this were so, it would still not account for the fact that all the cases of lung cancer were found in association with asbestosis.

It is, therefore, concluded that the fourth explanation is the most reasonable one and that the asbestos workers who had worked for 20 or more years in the "scheduled areas" suffered a notably higher risk from lung cancer than the rest of the population.

To test if the risk has altered since the 1931 regulations were introduced, it is not only necessary to make allowance for duration of employment before the end of 1932, but also to allow for the men's ages and for the total durations of their employment in the "scheduled areas", since the men employed in the earlier periods can also have been employed longer and lived to be older. On the other hand, there is no need to consider the changing incidence of lung cancer in the total population of England and Wales since the non-industrial risk has been shown to be small in comparison with the industrial one. The data required for comparing the risks among men employed for under 10 years, for 10 to 14 years, and for 15 years and over in the pre-1933 conditions are shown in Table 5. The ages shown are the ages at death of the men who have died and the ages in mid1953 for the men who are still alive. The expected numbers of men in each pre-1933 employment group found to have asbestosis or asbestosis and lung cancer are estimated by multiplying the numbers in each age, total employment, and pre-1933 employment subgroup by the proportions of men with asbestosis or with asbestosis and lung cancer in the same age and total employment group for all lengths of pre-1933 employment combined. For example, three out of the nine men aged 50 to 54 years who had 
TABLE 5

NUMBERS OF MEN EMPLOYED FOR DIFFERENT PERIODS BEFORE 1933 AND NUMBERS KNOWN TO HAVE ASBESTOSIS AND LUNG CANCER IN ASSOCIATION WITH ASBESTOSIS DIVIDED BY TOTAL DURATION OF EMPLOYMENT IN A SCHEDULED AREA AND BY AGE

\begin{tabular}{|c|c|c|c|c|c|c|c|c|c|c|c|c|c|}
\hline \multirow{3}{*}{$\begin{array}{c}\text { Total } \\
\text { Length of } \\
\text { Employment } \\
\text { in } \\
\text { " Scheduled } \\
\text { Area " } \\
\text { (years) }\end{array}$} & \multirow{3}{*}{$\begin{array}{c}\text { Age at } \\
\text { June 30, } \\
1953 \text {, } \\
\text { or at } \\
\text { Death } \\
\text { (years) }\end{array}$} & \multicolumn{9}{|c|}{ Length of Employment before January 1, 1933} & \multirow{2}{*}{\multicolumn{3}{|c|}{$\begin{array}{c}\text { All Lengths of Employ- } \\
\text { ment before } \\
\text { January } 1,1933 \\
\end{array}$}} \\
\hline & & \multicolumn{3}{|c|}{ 0-9 Years } & \multicolumn{3}{|c|}{ 10-14 Years } & \multicolumn{3}{|c|}{$15+$ Years } & & & \\
\hline & & $\begin{array}{l}\text { No. } \\
\text { of } \\
\text { Men }\end{array}$ & $\begin{array}{c}\text { No. of } \\
\text { Men with } \\
\text { Asbes- } \\
\text { tosis }\end{array}$ & $\begin{array}{c}\text { No. of } \\
\text { Men with } \\
\text { Cancer } \\
\text { of Lung }\end{array}$ & $\begin{array}{l}\text { No. } \\
\text { of } \\
\text { Men }\end{array}$ & $\begin{array}{c}\text { No. of } \\
\text { Men with } \\
\text { Asbes- } \\
\text { tosis }\end{array}$ & $\begin{array}{c}\text { No. of } \\
\text { Men with } \\
\text { Cancer } \\
\text { of Lung }\end{array}$ & $\begin{array}{l}\text { No. } \\
\text { of } \\
\text { Men }\end{array}$ & $\begin{array}{c}\text { No. of } \\
\text { Men with } \\
\text { Asbes- } \\
\text { tosis }\end{array}$ & \begin{tabular}{|c|} 
No. of \\
Men with \\
Cancer \\
of Lung
\end{tabular} & $\begin{array}{l}\text { No. } \\
\text { of } \\
\text { Men }\end{array}$ & $\begin{array}{c}\text { No. of } \\
\text { Men with } \\
\text { Asbes- } \\
\text { tosis }\end{array}$ & $\begin{array}{l}\text { No. of } \\
\text { Men with } \\
\text { Cancer } \\
\text { of Lung }\end{array}$ \\
\hline $20-24$ & $\begin{array}{l}35- \\
40- \\
45- \\
50- \\
55- \\
60- \\
65- \\
70- \\
75-9\end{array}$ & $\begin{array}{l}1 \\
4 \\
7 \\
3 \\
5 \\
3 \\
2 \\
0 \\
1\end{array}$ & $\begin{array}{l}\text { 二 } \\
1 \\
2 \\
3 \\
1 \\
0 \\
0 \\
1\end{array}$ & $\begin{array}{l}\overline{ } \\
\bar{\equiv} \\
\overline{ } \\
=\end{array}$ & $\begin{array}{l}1 \\
1 \\
0 \\
3 \\
2 \\
1 \\
0 \\
0 \\
0\end{array}$ & $\begin{array}{l}1 \\
1 \\
0 \\
3 \\
1 \\
1 \\
= \\
\end{array}$ & $\begin{array}{l}\bar{z} \\
\overline{1} \\
\bar{z} \\
\bar{z}\end{array}$ & $\begin{array}{l}0 \\
0 \\
1 \\
3 \\
0 \\
1 \\
1 \\
1 \\
0\end{array}$ & $\begin{array}{l}- \\
1 \\
3 \\
0 \\
1 \\
1 \\
1 \\
-\end{array}$ & $\begin{array}{l}= \\
1 \\
2 \\
0 \\
0 \\
1 \\
-\end{array}$ & $\begin{array}{l}2 \\
5 \\
8 \\
9 \\
7 \\
5 \\
3 \\
1 \\
1\end{array}$ & $\begin{array}{l}1 \\
1 \\
2 \\
8 \\
4 \\
3 \\
1 \\
1 \\
1\end{array}$ & $\begin{array}{l}\bar{Z} \\
\overline{1} \\
3 \\
0 \\
0 \\
1 \\
=\end{array}$ \\
\hline $25-29$ & $\begin{array}{l}40- \\
45- \\
50- \\
55- \\
60- \\
65- \\
70- \\
75- \\
80-4\end{array}$ & $\begin{array}{r}3 \\
10 \\
6 \\
6 \\
3 \\
1 \\
0 \\
0 \\
0\end{array}$ & $\begin{array}{l}\overline{2} \\
2 \\
1 \\
= \\
= \\
=\end{array}$ & $\begin{array}{l}\bar{z} \\
= \\
\bar{z} \\
\bar{z}\end{array}$ & $\begin{array}{l}0 \\
2 \\
0 \\
8 \\
1 \\
1 \\
0 \\
0 \\
0\end{array}$ & $\begin{array}{l}-1 \\
0 \\
4 \\
1 \\
1 \\
= \\
-\end{array}$ & $\begin{array}{l}\overline{1} \\
0 \\
0 \\
0 \\
1 \\
= \\
=\end{array}$ & $\begin{array}{l}\mathbf{0} \\
\mathbf{0} \\
\mathbf{0} \\
\mathbf{1} \\
\mathbf{3} \\
\mathbf{0} \\
\mathbf{1} \\
\mathbf{1} \\
\mathbf{1}\end{array}$ & $\begin{array}{l}\text { 三 } \\
\overline{1} \\
1 \\
3 \\
0 \\
0 \\
1 \\
0\end{array}$ & $\begin{array}{l}= \\
\bar{Z} \\
1 \\
0 \\
0 \\
1\end{array}$ & $\begin{array}{r}3 \\
12 \\
6 \\
15 \\
7 \\
2 \\
1 \\
1 \\
1\end{array}$ & $\begin{array}{l}0 \\
3 \\
2 \\
6 \\
4 \\
1 \\
0 \\
1 \\
0\end{array}$ & $\begin{array}{l}-1 \\
1 \\
0 \\
1 \\
1 \\
0 \\
1 \\
-\end{array}$ \\
\hline $30-34$ & $\begin{array}{l}45- \\
50- \\
55- \\
60- \\
65- \\
70-4\end{array}$ & $\begin{array}{l}2 \\
2 \\
1 \\
1 \\
0 \\
0\end{array}$ & $\begin{array}{l}\bar{z} \\
\bar{z}\end{array}$ & $\begin{array}{l}\bar{z} \\
\bar{z}\end{array}$ & $\begin{array}{l}0 \\
5 \\
1 \\
0 \\
0 \\
0\end{array}$ & $\begin{array}{l}\bar{z} \\
\bar{z}\end{array}$ & $\begin{array}{l}\bar{z} \\
\bar{z}\end{array}$ & $\begin{array}{l}0 \\
2 \\
3 \\
2 \\
0 \\
1\end{array}$ & $\begin{array}{l}\overline{-} \\
2 \\
1 \\
0 \\
1\end{array}$ & $\frac{\overline{1}}{\overline{1}}$ & $\begin{array}{l}2 \\
9 \\
5 \\
3 \\
0 \\
1\end{array}$ & $\begin{array}{l}0 \\
0 \\
2 \\
1 \\
0 \\
1\end{array}$ & $\begin{array}{l}\overline{1} \\
\bar{z}\end{array}$ \\
\hline $35+$ & $\begin{array}{l}55- \\
60- \\
65-9\end{array}$ & $\begin{array}{l}\mathbf{0} \\
\mathbf{0} \\
\mathbf{0}\end{array}$ & 三 & 二 & $\begin{array}{l}\mathbf{0} \\
\mathbf{0} \\
\mathbf{0}\end{array}$ & 二 & 三 & $\begin{array}{l}1 \\
1 \\
2\end{array}$ & 三 & 三 & $\begin{array}{l}1 \\
1 \\
2\end{array}$ & $\begin{array}{l}\mathbf{0} \\
0 \\
\mathbf{0}\end{array}$ & 三 \\
\hline $\begin{array}{c}\text { All } \\
\text { lengths of } \\
\text { employment } \\
\text { in a } \\
\text { " scheduled } \\
\text { area" } \\
(20 \text { yrs. }+ \text { ) }\end{array}$ & $\begin{array}{l}35- \\
40- \\
45- \\
50- \\
55- \\
60- \\
65- \\
70- \\
75- \\
80-4\end{array}$ & $\begin{array}{r}1 \\
7 \\
19 \\
11 \\
12 \\
7 \\
3 \\
0 \\
1 \\
0 \\
\end{array}$ & $\begin{array}{l}\text { 二 } \\
3 \\
4 \\
4 \\
1 \\
0 \\
0 \\
1 \\
-\end{array}$ & $\begin{array}{l}= \\
= \\
= \\
= \\
=\end{array}$ & $\begin{array}{r}1 \\
1 \\
2 \\
8 \\
11 \\
2 \\
1 \\
0 \\
0 \\
0 \\
\end{array}$ & $\begin{array}{l}1 \\
1 \\
1 \\
3 \\
5 \\
2 \\
1 \\
= \\
=\end{array}$ & $\begin{array}{l}\bar{Z} \\
1 \\
1 \\
0 \\
0 \\
1 \\
= \\
=\end{array}$ & $\begin{array}{l}0 \\
0 \\
1 \\
5 \\
5 \\
7 \\
3 \\
3 \\
1 \\
1 \\
\end{array}$ & $\begin{array}{l}\text { 二 } \\
1 \\
3 \\
3 \\
5 \\
1 \\
2 \\
1 \\
0\end{array}$ & $\begin{array}{l}\text { 二 } \\
1 \\
2 \\
1 \\
1 \\
1 \\
0 \\
1 \\
\end{array}$ & $\begin{array}{r}2 \\
8 \\
22 \\
24 \\
28 \\
16 \\
7 \\
3 \\
2 \\
1 \\
\end{array}$ & $\begin{array}{r}1 \\
1 \\
5 \\
10 \\
12 \\
8 \\
2 \\
2 \\
2 \\
0 \\
\end{array}$ & $\begin{array}{l}\overline{ } \\
2 \\
4 \\
1 \\
1 \\
2 \\
0 \\
1 \\
\end{array}$ \\
\hline & All ages & 61 & 13 & 1 & 26 & 14 & 3 & 26 & 16 & 7 & 113 & 43 & 11 \\
\hline
\end{tabular}

been employed for 20 to 24 years in the areas in which they might be exposed to asbestos dust were found to have asbestosis and lung cancer. Since three men had worked for under 10 years in the pre1933 conditions, three had worked for 10 to 14 years, and three had worked for 15 or more years, the expected number of cases in each of the pre-1933 employment groups would have been the same, i.e., $3 \times 3 / 9$, or 1 . In fact, the numbers of cases found were 0,1 , and 2 . The total numbers expected in each pre-1933 employment group are obtained by adding the numbers calculated for each of the age and total employment groups within it. The results are as follows :

The differences between the numbers of men observed and the numbers expected in each employment group, had the incidence of the conditions remained steady throughout, are statistically signi- ficant (total asbestosis, $\chi^{2}=7 \cdot 52, \mathrm{n}=2, \mathrm{P}=0.025$; asbestosis and lung cancer, $\chi^{2}=8 \cdot 74, \mathrm{n}=2$, $\mathbf{P}=0.01^{*}$ ). They are highly so if the trend, that is,

\begin{tabular}{|c|c|c|c|}
\hline & \multicolumn{3}{|c|}{$\begin{array}{c}\text { Length of Employment before } \\
\text { January 1, 1933 }\end{array}$} \\
\hline & $\begin{array}{l}\text { Under } \\
10 \text { Years }\end{array}$ & $\begin{array}{l}10-14 \\
\text { Years }\end{array}$ & $\begin{array}{l}15 \text { Years } \\
\text { and Over }\end{array}$ \\
\hline $\left.\begin{array}{l}\text { Total number of men } \\
\text { with asbestosis }\end{array}\right\} \begin{array}{l}\text { observed } \\
\text { expected }\end{array}$ & $\begin{array}{l}13 \\
21 \cdot 9\end{array}$ & $\begin{array}{l}14 \\
10 \cdot 3\end{array}$ & $\begin{array}{l}16 \\
10 \cdot 8\end{array}$ \\
\hline $\left.\begin{array}{l}\text { Number of men with } \\
\text { asbestosis and lung } \\
\text { cancer }\end{array}\right\} \begin{array}{l}\text { observed } \\
\text { expected }\end{array}$ & $\frac{1}{5 \cdot 5}$ & $\begin{array}{l}3 \\
2 \cdot 4\end{array}$ & $\begin{array}{l}7 \\
3 \cdot 1\end{array}$ \\
\hline
\end{tabular}

* The expected numbers of lung cancer are small and the probability that the differences could arise by chance has consequently been somewhat, but not seriously, underestimated. If all men with more than 10 y , but not seriously, underestimated. correction made for small numbers, $x^{2}=5.82, n=1, P=0.02$. 
the biologically important reduction in the proportion between observed and expected numbers as the length of pre-1933 employment is reduced, is also taken into consideration. It is clear, therefore, that the incidences both of asbestosis and of lung cancer associated with asbestosis have become progressively less as the number of years during which men were exposed to the pre-1933 conditions has decreased.

The extent of the risk of lung cancer over the whole period among the men studied appears to have been of the order of 10 times that experienced by other men. This agrees well with the data reported by Merewether (1949), but it is somewhat greater than that suggested by Gloyne's data (1951). The great reduction in the amount of dust produced in asbestos works during the period has been accompanied by a reduction in the incidence of lung cancer among the workmen so that the risk before 1933 is likely to have been considerably greater-perhaps 20 times the general risk. Whether the specific industrial risk of lung cancer has yet been completely eliminated cannot be determined with certainty; the number of men at risk, who have been exposed to the new conditions only and who have been employed for a sufficient length of time, is at present too small for confidence to be placed in their experience. It is clear, however, that the risk has for some time been greatly reduced. The extent of the reduction is particularly striking when it is recalled that between 1933 and 1953 the incidence of the disease among men in the country at large has increased sixfold.

\section{Summary}

The cause of death, as determined at necropsy, is reported for 105 persons who had been employed at one asbestos works. Lung cancer was found in $\mathbf{1 8}$ instances, 15 times in association with asbestosis. All the subjects in whom both conditions were found had started employment in the industry before 1923 and had worked in the industry at least nine years before the regulations for the control of dust had become effective.
One hundred and thirteen men who had worked for at least 20 years in places where they were liable to be exposed to asbestos dust were followed up and the mortality among them compared with that which would have been expected on the basis of the mortality experience of the whole male population. Thirty-nine deaths occurred in the group whereas 15.4 were expected. The excess was entirely due to excess deaths from lung cancer (11 against 0.8 expected) and from other respiratory and cardiovascular diseases (22 against 7.6 expected). All the cases of lung cancer were confirmed histologically and all were associated with the presence of asbestosis.

From the data it can be concluded that lung cancer was a specific industrial hazard of certain asbestos workers and that the average risk among men employed for 20 or more years has been of the order of 10 times that experienced by the general population. The risk has become progressively less as the duration of employment under the old dusty conditions has decreased.

I would like to offer my thanks to the management of the firm concerned for permission to carry out this work and to the Medical Officer and members of the staff of the works where the men were employed, who carried out the greater part of the work on which this report is based.

\section{REFERENCES}

Asbestos Industry Regulations (1931). Statutory Rules and Orders, 1931, No. 1140 . H.M.S.O., London.

Boemke, F. (1953). Med. Mschr., 7, 77.

Cartier, P. (1952). Arch. industr. Hyg., 5, 262 (contribution to discussion).

Council of the International Organizations of Medical Sciences (1953). Acta Un. int. Cancr., 9, 443.

Doll, R. (1953). Brit. med. J., 2, 521 .

Gloyne, S. R. (1951). Lancet, 1, 810.

Hueper, W. C. (1952). Proceedings of the Seventh Saranac Symposium. To be published.

Lynch, K. M., and Smith, W. A. (1935). Amer. J. Cancer, 24, 56. Merewether, E. R. A. (1949). Annual Report of the Chief Inspector of Factories for the Year 1947. H.M.S.O., London

Nordmann, M., and Sorge, A. (1941). Z. Krebsforsch., 51, 168.

Smith, W. E. (1952). Arch. industr. Hyg., 5, 209.

Smith, W. E. (1952), Arch. industr. Hyg
Stocks, P. (1952). Brit. J. Cancer, 6, 99.

Vorws, P. (1952). Brit. J. Cancer, 6, 99. Amer. J. Path., 14, 49.

Warren, S. (1948). Occup. Med., $5,249$. 